\title{
指紋画像に対する指の表面状態の影響
}

\author{
正会員 橋 本 哲 ${ }^{\dagger}$, 畑豊 ${ }^{\dagger}$ \\ 三 好 義 昭 ${ }^{\dagger}$, 正会員 大 和 一 晴 ${ }^{\dagger}$
}

\section{The Effect of the Skin Condition on a Fingerprint Image}

\author{
Satoshi Hashimoto ${ }^{\dagger}$, Yutaka Hata ${ }^{\dagger}$, Yoshiaki Miyoshi $^{\dagger}$ \\ and Kazuharu Yamato ${ }^{\dagger}$
}

\begin{abstract}
Total reflection and light-path separation are the primary methods used to detect fingerprint image. Skin condition and illumination intensity influence the image quality. We investigate the influence of these factors on fingerprint images detected by both methods. With dry skin, the reflection method cannot resolve features necessary for identification, but the light-path separation method can. With wet skin, both methods are effective. For both methods, the optimal illumination intensity depends on the skin condition. The light-path separation method is superior to total reflection method.
\end{abstract}

\section{1. まえがき}

近年, 様々なコンピュータシステムが開発され, 我々の社会生活は便利になった。しかし、これらのシ ステムの中には銀行の ATM (現金自動預け払い機)の ように高いセキュリティが要求されているにもかかわ らず無人化に加え比較的単純なチェックしか行われな いものもあり，第三者による不正使用の問題が指摘さ れている。

このような背景から, 個人固有の特徵である音声や 指紋による個人確認がより安全性に優れた方法として 注目されている，特に指紋は「万人不同」，「終生不変」
という 2 大特徵を持ち, 個人確認の最も確実な手段と 考えられ, 指紋照合装置の研究, 開発が各地で盛んに 行われている 、筆者らも ICカードを用いた簡易型 指紋照合装置を開発した ${ }^{2)}$.このような指紋照合装置 は, 高精度はいうまでもなく小型化と高速性も要求さ れているため, 画像処理と照合処理は複雑であっては ならない。そのため, 入力指紋画像は常に良質である 必要があり, 指紋検出方法の良否が照合精度を左右す る. 基本的な指紋検出方法としてプリズムを用いた全 反射法 ${ }^{3)}$ 光路分離法 ${ }^{4)}$ がある。また, 装置の小型化 が容易で検出画像に歪みの生じない方法として, ホロ グラムを利用したホログラフィック指紋センサ ${ }^{5}$ や光

キーワード：指紋, 入力方式, 評価

1988 年 11 月 25 日, テレビジョン学会技術報告に発表

1989 年 8 月 21 日受付, 1990 年 3 月 26 日最終受付

$\dagger$ 姫路工業大学 工学部 (

$\dagger$ Faculty of Engineering, Himeji Institute of Technology (2167, Shosha, Himegi, Hyogo 671-22, Japan) 
学系に押しつけた指を光源とセンサが機械的にスキャ ンする方法吕が報告されている，いずれの方法も本人 の意志で指紋を入力するとはいえ, 指の表面状態の変 化等により検出画像は影響を受け, 照合精度の低下が 予想される。

本論文では全反射法と光路分離法について指の表面 状態等がどの程度検出画像の画質に影響を与えるかを 調べた。その結果, 指の表面が乾燥していた場合, 全 反射法による検出画像の品質は著しく劣化し, 照合に 必要な指紋情報の抽出が困難である。一方, 光路分離 法では指表面の乾燥により検出画像の質は劣化するが 比較的安定して指紋情報が抽出でき, 高精度の照合が 可能であることを確認した.

\section{2. 指紋検出方法}

指紋画像の検出方法を大別すると次の 2 つになる. ひとつは指にインクを付けて紙などに押捺した指紋を FSS (Flying Spot Scanner)や CCD (Charge Coupled Device) スキャナで読取る方法であり，もうひとつは インクを用いずに異種媒質間における光の反射, 屈折 の法則を利用して検出した指紋像をテレビカメラ等で 撮影する方法である，後者の方法は，手を污すことな く容易に指紋を入力できる点で, 指紋による個人確認 システムに適している．本稿では後者の指紋検出方法 を議論の対象とする。

\section{1 光の全反射条件}

まず，異種媒質間における光のふるまいについて簡 単に説明しておく．ある境界面で屈折率がそれぞれ $n_{1}$ と $n_{2}\left(n_{1}>n_{2}\right)$ の媒質 1 と媒質 2 が接し, 光が媒質 1 から入射角 $\theta_{1}$ で媒質 2 入入射する場合, 全反射臨 界角 $\theta_{0}$ はスネルの法則より次式で与えられる.

$$
\theta_{0}=\sin ^{-1} \frac{n_{2}}{n_{1}}
$$

ここで $\theta_{1}>\theta_{0}$ を全反射条件といい, 入射角 $\theta_{1}$ が $\theta_{0}$ よ りも大きいとき光は境界面で全反射される。

\section{2 プリズムを用いた指紋検出の原理}

図 1 に全反射法 ${ }^{3)}$ と光路分離法 ${ }^{4)}$ の原理を示す. 全 反射法の場合, 光源はプリズム斜面のガラス/空気境 界面で全反射条件を満たすように置かれる。この場 合, 光源からの光はプリズムに接触しない指紋山部 (谷の部分) で全反射される。一方, プリズムに接触す る指紋凸部（隆線部分）では指表面の水分と油分の屈 折率が空気の屈折率より大きいため, 全反射条件が満 たされなくなり光源からの光は散乱される.この方法 では全反射光による明るい背景に対して, 隆線部分の 暗い指紋画像が検出される。
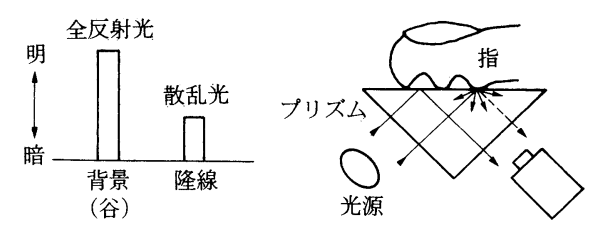

（a）全反射法
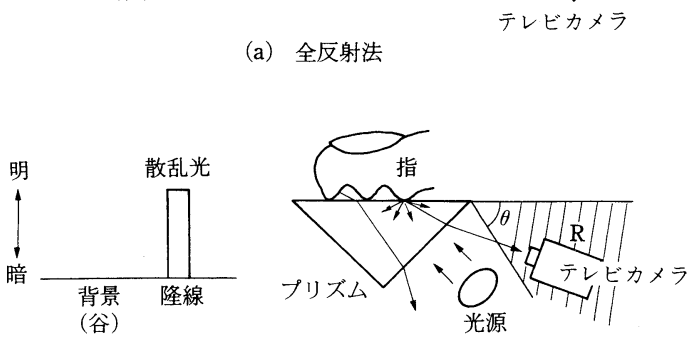

(b) 光路分離法

図 1 指紋検出方法の原理と光レベル Principle of detecting fingerprint and light level.

光路分離法の場合, 光源はプリズムを通して指の表 面全体を照らしている．プリズムに接触しない指紋凹 部での散乱光は, 空気中からプリズムへ入射した後, 再び空気中へ抜けるが，スネルの法則により図 1 (b) 中の領域 $\mathrm{R}^{4)}$ には到達できない。この領域 $\mathrm{R} に は$ は指 紋凸部での散乱光の一部が到達でき, ここに TVカ メラを設置すれば，暗い背景に対して隆線部分の明る い指紋画像が検出できる.

\section{3 ホログラフィック指紋センサの原理}

図 2 のように透明なガラス平板の一端に指紋入力部 がありレーザ光が照射されている．ガラスに接触する 指紋凸部での散乱光のうち, 全反射臨界角以上でガラ スに入射した光はガラス/空気界面で全反射しながら 平板状導光板の中を伝搬する.この光を導光板の一部 に形成したホログラムを用いて映像化する．光路分離 法と同様に, 背景光がなく指紋凸部における散乱光の みを検出するので, 暗い背景の中に明るい隆線の像と

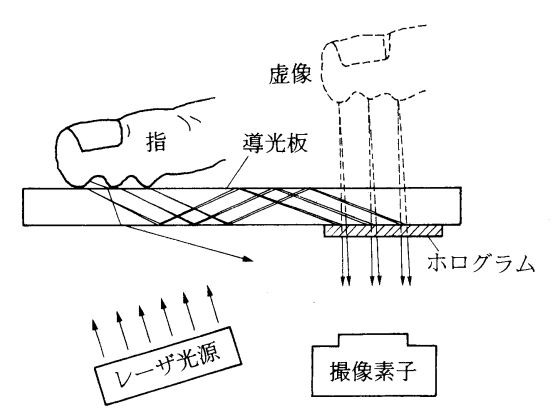

図 2 ホログラフィック指紋センサの原理 Principle of holographic fingerprint sensor. 

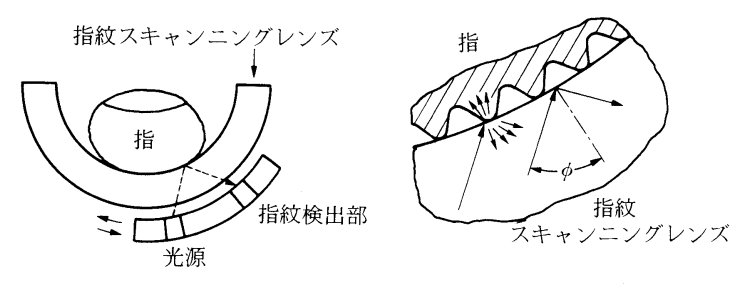

図 3 全反射スキャンニング法の原理

Principle of total reflection scanning.

なる。

\section{4 全反射スキャンニング法の原理}

本稿ではこの光学系を指紋スキャンニングレンズと 呼ぶ. 図 3 のように光の入射角 $\phi$ が全反射臨角以上 の時, 光は指紋凹部で全反射し指紋凸部で散乱され る. 指紋検出部はこの全反射光と散乱光の両方を検出 できる位置に置かれ, 光源と検出部はそれぞれの位置 関係を保ったまま回転し指紋全体をスキャンする，全 反射法と同様に，指紋が入力されていないとき全反射 光がすべて検出部に入射し, 指紋が入力されると指紋 凸部で発生した散乱光のために検出部へ入射する全反 射光が減少し, 明るい背景光の中に隆線部分の暗い像 となる。

画像生成の方法が類似しているホログラフィック指 紋センサと光路分離法, 全反射スキャンニング法と全 反射法による画像は, それぞれ同様の性質を持つと考 えられる。また実験システムの構築が容易なことか ら, 実験は全反射法と光路分離法について行うことに する。

\section{3. 実 験}

光学的に指紋を検出する方法では, 照明の強さやプ リズム面の污れ，指表面の湿り具合い等により検出画 像の質は変化する，実験ではサンプルとして指表面に 外傷がなく隆線と谷部の山凸が明瞭な指紋を選び，全 反射法と光路分離法による検出画像の質と照合結果 が, これらの条件によりどの程度影響を受けるか調べ た。

\section{1 実験装置の構成}

図 4 に実験装置の構成を示す，押捺された指紋はテ レビカメラで映像化され A/D 変換器で 256 階調の濃 淡画像に変換される. 実験に用いたテレビカメラの $\gamma$ 特性は $\gamma=1.0$, すなわち, 被写体の明るさと映像信 号の大きさとの関係は線形とし, $\mathrm{A} / \mathrm{D}$ 変換器の特性 は最小映像信号 (黒レベル) をレベル 255, 最大映像信

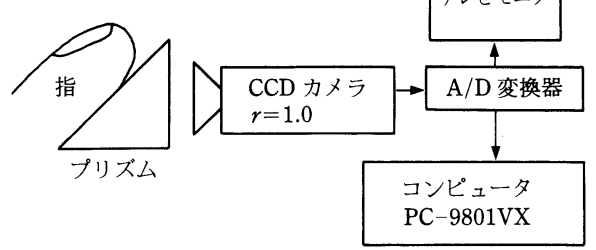

図 4 実験装置の構成

Configuration of simulation system.
号（白レベル）をレベル 0 とした．本稿ではこの 0〜255 の各レベル值を濃度值と定義する。

\section{2 画質の評価值}

入力画像は指紋の隆線部分と谷部分がはっきりして いて，容易に連続した線として識別できるものが好ま しい。このためには隆線部分と谷部分との濃度差は大 きいほど良いと考えられる。本稿では隆線部分と谷部 分との濃度差を評価する尺度として濃度值の標準偏差 $\sigma$ を用い, 光源の最適な明るさを決めるのに用いる。 そして, 最適な光源下で入力されたサンプルについ て, 大津の評価尺度 $\eta^{* 7)}$ を用いて隆線部分と谷部分の 分離の良さを評価することにした。

(1) 濃度値の標準偏差 $\sigma$

標準偏差 $\sigma$ は総画素数 $n$ の $i$ 番目の画素の濃度值 を $f(i)$ とすると,

$$
\sigma=\sqrt{\sum_{i=1}^{n}\{f(i)-\mu\}^{2} / n}
$$

で与えられる。ここで，

$$
\mu=\sum_{i=1}^{n} f(i) / n
$$

である. 標準偏差 $\sigma$ は平均濃度值からのちらばりの 程度を表し，高コントラストの画像ほど大きくなる。

(2) クラスの分離度の最大值 $\eta^{*}$

質の良い指紋画像のヒストグラムには，隆線部分と 背景部分に対応する 2 つの山が現れる(ヒストグラム の双峰性)。しかし，隆線のかすれなどにより画質が 低下すると山の形は崩れ，七ストグラムは双峰性を示 さなくなる。このヒストグラムの双峰性が指紋画像の 画質を評価するための指標となり得る．大津により隆 線部分と背景部分という 2 つクラスの分離度の最大 值 $\eta^{*}$ がヒストグラムの双峰性を示す尺度となること が報告されている ${ }^{7)}$.クラスの分離度 $\eta$ はクラス間分 散 $\sigma_{B}^{2}$ と全分散 $\sigma_{T}^{2}$ の比,

$$
\eta=\frac{\sigma_{B}^{2}}{\sigma_{T}^{2}}
$$


で定義される，ここで $\sigma_{B}^{2}$ は，

$$
\sigma_{B}^{2}=\omega_{1}\left(\mu_{1}-\mu_{T}\right)^{2}+\omega_{2}\left(\mu_{2}-\mu_{T}\right)^{2}
$$

である.ただし， $\omega_{1}, \omega_{2}, \mu_{1}, \mu_{2}$ は 2 つのクラスの生起 確率と平均值であり $\mu_{T}$ は全体の平均值である.クラ スの分離度 $\eta$ は $0 \leqq \eta \leqq 1 の$ 值をとり, ある 2 值化閾 值のとき最大となる．その最大值 $\eta^{*}$ はヒストグラム に双峰性があるときほど大きくなり，隆線がかすれて いて中間的な濃度值が多く存在すると低下する。

\section{4. 実験結果および考察}

\section{1 標準偏差 $\sigma$ による評価}

検出画像のコントラストを最高にする光源の明るさ と, いずれの検出方法がコントラストの点で優れてい るかを調べた. 光源に白熱電球を用い光源の照度と標 準偏差 $\sigma$ の関係を調べた結果を図 $\mathbf{5}$ に示す．この測 定でテレビカメラの絞りは被写体深度を深くとる目的 から最も絞った状態に固定した。これは指紋入力面を 斜めから撮影するために生じるピンボケを押さえるた めである. また, 本稿でいう照度は光源の照度で, 全 反射法では光源とプリズム間に散乱フィルタをおくた め, 指の表面に到達する光は光路分離法に比べ弱くな る。

指紋入力条件として, 指表面を油で湿らせた wet 状態とドライヤで乾燥させた dry 状態を設定した. この 2 つの状態は両極端なものではあるが, 通常の入 力でも生じ得る状態である。 またプリズム指紋入力面 の状態として, 表面が清浄な clean 状態と残留指紋に より污れている dirty 状態を設定した. 図 5 はそれぞ れの照度において同一指の 20 回入力による平均值を プロットした結果である。

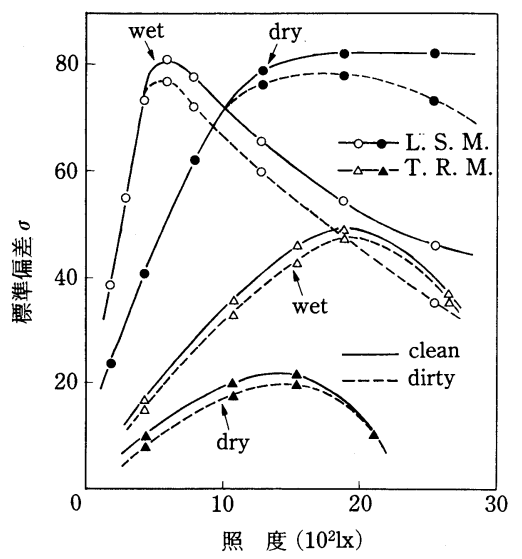

図 5 標準偏差 $\sigma$ にる評価結果 Result of evaluation by $\sigma$.
図 5 より, 全体的に光路分離法 (図中の L.S. M.)の 方が $\sigma$ は大きくっている，これは，全反射法（図中 の T. R. M.) による画像では光源の照度が上昇するに つれて全反射法による明るい背景と共に隆線部分から の散乱光も明るくなるが, 光路分離法では暗い背景は そのままで隆線部分の明るさのみが増すためである.

指の表面状態による相違については, 全反射法の場

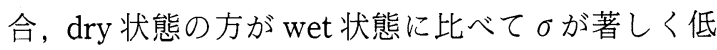
下した。これは指表面の水分と油分がそしいdry 状 態ではプリズムに接触する指紋凸部での散乱光が弱く なり，明るい背景との明暗差が小さくなるためであ る。この場合，いかなる照度設定を行っても wet 状 態と同程度のコントラストは得られない。一方, 光路 分離法でも dry 状態ではプリズムに接触する指紋凸 部からの散乱光は弱くなるが，照明を明るくすること により wet 状態と同程度のコントラストが得られて いる.両方法とも濃度值が飽和してくると暗の部分が

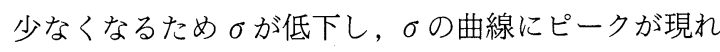
る. 光路分離法の wet 状態では指紋凸部周辺の過㮃 な水分と油分による散乱光が無視できなくなり, 散乱 光が強くなる高照度側で $\sigma か ゙$ 低下している.

指紋入力面の污れの影響については，両方法ともに $\sigma か ゙$ 低下した，全反射法の場合，プリズムに付着した 污れが指紋凹部でのプリズム/空気界面での全反射条 件を乱すためである ${ }^{9)}$. 光路分離法でも污れにより指 紋凹部で散乱光が発生しカメラに入射する.この 低下現象は散乱光が強くなる高照度側で顕著に現れ た。

\section{2 クラスの分離度による評価}

サンプル画像の入力と $\eta^{*}$ 值の測定に先立ち, wet とdry 状態の指紋が共に安定して検出できる照度值 を図 5 より決定した. 光路分離法については wet と dry 状態の両曲線が交わって同じ $\sigma$ となる $1000 \mathrm{~lx} に$ 設定した．全反射法では wet に比べコントラストが 著しく低いdry 状態で最良の画像検出が期待できる 曲線最大值の $1700 \mathrm{~lx}$ に設定した。

図 6 に検出画像の例と細線画像およびヒストグラム を示す.ここで, 全反射法と光路分離法による検出画 像は互いに反転関係にあるので, 同図の結果は光路分 離法による画像を反転して求めたものである. 指紋画 像は $16 \times 16$ 画素(全画面は $256 \times 240$ 画素)の各部分領 域ごとに平均濃度值を求め, それを閾值とした 2 值画 像で, 白い部分が指紋凹部, 黒い部分が指紋凸部であ る. 細線画像は, 微分オペレータを用いた谷細線化処 理9によるものである。また，ヒストグラムは全体の 形を見易くするため, 光路分離法の縦軸「頻度」のス 

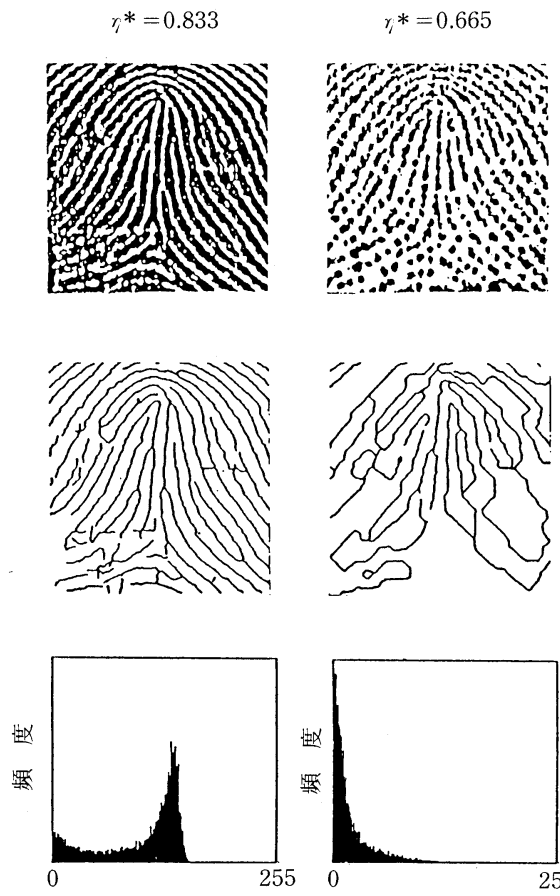

濃度値

wet 状態

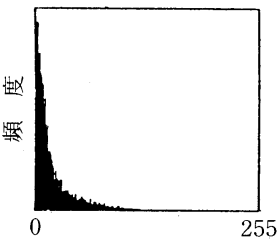

濃度値

dry 状態

(a) 全反射法
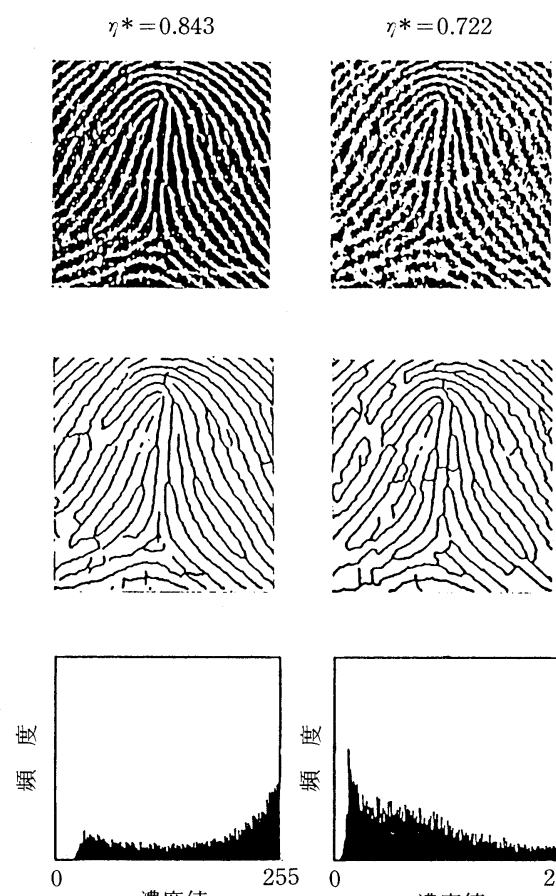

濃度值

wet 状態

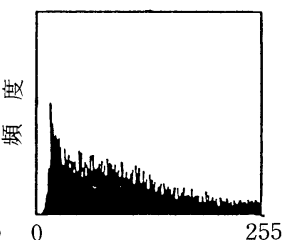

濃度值

dry 状態

（b）光路分離法

図 6 指紋画像と細線画像，およびヒストグラム

Fingerprint images, line images and histograms.

ケールを全反射法の $1 / 2$ にしている。

wet 状態では両方法ともヒストグラムに双方性が見 られ, クラスの分離度の最大值 $\eta^{*}$ は,
（a） 全反射法 : $\eta^{*}=0.833$
（b） 光路分離法： $\eta^{*}=0.843$

と大きく，良質の指紋画像と細線画像が得られてい る。両方法とも指紋凸部だけでなく過剒な水分と油分 がプリズムに接触するため実質的な接触面積は dry 状態より広くなり，ヒストグラムの分布は隆線情報に 相当する高濃度值側が大きくなっている．濃度值分布 範囲(横軸方向)については光路分離法の方が広く, コ ントラストの高いことがわかる。

一方, dry 状態では両方法とも指紋凸部での散乱光 が弱くなるためクラスの分離度の最大值 $\eta^{*}$ が,

\section{(a) 全反射法 $: \eta^{*}=0.665$ \\ （b）光路分離法： $\eta^{*}=0.722$}

と低下し，指紋画像には隆線の切れが目立つ。特に全 反射法ではヒストグラムの濃度值分布範囲が狭くな り, 細線画像には大きな線分の欠落が見られる。一 方, 光路分離法では濃度值分布範囲が wet 状態と同
程度に保たれていることから, 比較的良好な細線画像 が得られ ${ }^{10) 11)}$, 全反射法ほどの画質低下は認められな い.

図 7 に検出画像の標準偏差 $\sigma$ とクラスの分離度の 最大值 $\eta^{*}$ の関係を示す. サンプル指紋は成人男子 12 人に同一指を各 10 回ずつ入力してもらった 120 指を 用いた. 同図より光路分離法の方が右上に分布したこ とから全反射法に比べ検出画像が良質であったことが わかる。また, 同図 ( a ), ( b ) 共に同図 ( b ) に円で囲 んだサンプルを除くとのと $\eta^{*}$ の間に相関のあること もわかる．図中に円で囲んだサンプルは著しく wet な同一指によるもので, 中間的な濃度值が少ないため ク*は高いままだが, 過剰な水分のために明るい隆線

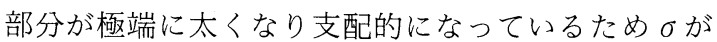
低下していた。このような例はサンプル数が少ないな がら本実験で得た結果から，その出現確率は数\%以下 と思われる。

\section{3 照合結果による比較}

本節では評価をさらに一歩進めて, 指紋情報の抽出 率と照合率について比較する。実験では図 8 に示す流 


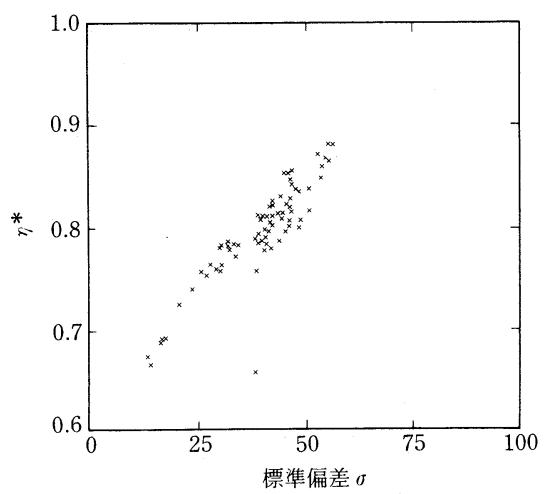

(a) 全反射法

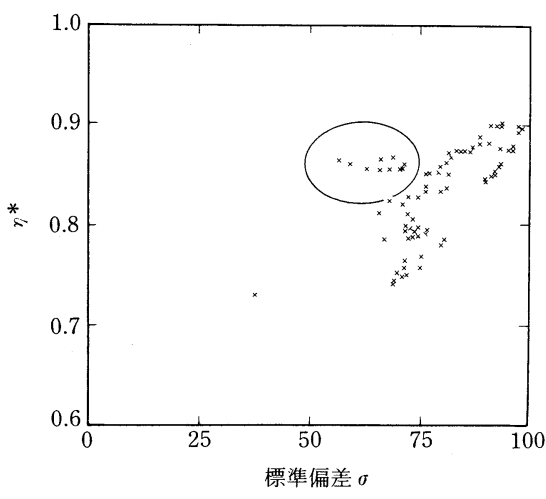

(b) 光路分離法

図 7 クラス分離度の最大値 $\eta^{*}$ による評価結果 Result of evaluation by $\eta^{*}$.

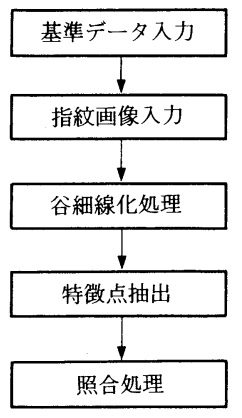

図 8 指紋照合の流れ

Flow diagram of fingerprint identification.

れに沿って指紋照合を行った。まず，筆者らが提案し た谷細線化法 ${ }^{9}$ により細線化し特徵点（端点, 分岐点) の位置と方向コードを指紋情報として抽出する，次 に, 特徵点のテンプレートマッチングにより登録指紋 と入力指紋との照合を行う ${ }^{12)}$ 。このような照合方法で 高精度の結果を得るためには, 正確な特徵点抽出が必
表 1 特徵点抽出率による評価結果

Result of extracting rate of minutiae.

\begin{tabular}{c|c|c|c|c|c|c}
\hline \hline \multirow{2}{*}{$\begin{array}{c}\text { サン } \\
\text { プル }\end{array}$} & \multicolumn{3}{|c|}{ 全反射法 } & \multicolumn{3}{|c}{ 光路分離法 } \\
\cline { 2 - 7 } & $\eta^{*}$ & $\begin{array}{c}\text { 正抽出率 } \\
(\%)\end{array}$ & $\begin{array}{c}\text { 擬似特徵率 } \\
(\%)\end{array}$ & $\eta^{*}$ & $\begin{array}{c}\text { 正抽出率擬似特徵率 } \\
(\%)\end{array}$ & $\begin{array}{c}\% \\
(\%)\end{array}$ \\
\hline $\mathrm{A}$ & 0.881 & 90.5 & 17.4 & 0.898 & 90.5 & 17.4 \\
\hline $\mathrm{B}$ & 0.830 & 71.4 & 23.1 & 0.877 & 86.7 & 7.1 \\
\hline $\mathrm{C}$ & 0.830 & 87.0 & 28.6 & 0.858 & 87.0 & 28.6 \\
\hline $\mathrm{D}$ & 0.814 & 75.0 & 28.9 & 0.867 & 77.1 & 15.6 \\
\hline $\mathrm{E}$ & 0.854 & 88.9 & 33.3 & 0.903 & 100.0 & 40.0 \\
\hline $\mathrm{F}$ & 0.827 & 75.0 & 33.3 & 0.857 & 78.8 & 36.6 \\
\hline $\mathrm{G}$ & 0.812 & 70.0 & 34.4 & 0.883 & 86.7 & 43.5 \\
\hline $\mathrm{H}$ & 0.808 & 63.2 & 78.6 & 0.856 & 65.0 & 66.7 \\
\hline $\mathrm{I}$ & 0.796 & 63.2 & 61.3 & 0.833 & 64.7 & 64.5 \\
\hline $\mathrm{J}$ & 0.765 & 57.1 & 62.8 & 0.805 & 60.7 & 67.9 \\
\hline $\mathrm{K}$ & 0.783 & 57.1 & 77.8 & 0.793 & 57.9 & 76.6 \\
\hline $\mathrm{L}$ & 0.684 & 42.3 & 71.1 & 0.750 & 62.5 & 67.4 \\
\hline 総合 & 0.807 & 70.1 & 45.9 & 0.848 & 76.5 & 44.3 \\
\hline
\end{tabular}

表 2 照合率による評価結果

Result of identification rate.

\begin{tabular}{c|c|c|c|c}
\hline \multirow{2}{*}{\begin{tabular}{c} 
サン \\
\cline { 2 - 5 }
\end{tabular}} & \multicolumn{2}{|c|}{ 全反射法 } & \multicolumn{2}{c}{ 光路分離法 } \\
\cline { 2 - 5 } $\mathrm{A}$ の平均 & $\begin{array}{c}\text { 照合率 } \\
(\%)\end{array}$ & $\eta^{*}$ の平均 & $\begin{array}{c}\text { 照合率 } \\
(\%)\end{array}$ \\
\hline $\mathrm{B}$ & 0.858 & 100 & 0.890 & 100 \\
\hline $\mathrm{C}$ & 0.822 & 100 & 0.862 & 100 \\
\hline $\mathrm{D}$ & 0.813 & 100 & 0.832 & 100 \\
\hline $\mathrm{E}$ & 0.845 & 100 & 0.893 & 100 \\
\hline $\mathrm{F}$ & 0.812 & 100 & 0.856 & 100 \\
\hline $\mathrm{G}$ & 0.806 & 100 & 0.877 & 100 \\
\hline $\mathrm{H}$ & 0.807 & 80 & 0.853 & 90 \\
\hline $\mathrm{I}$ & 0.794 & 90 & 0.822 & 90 \\
\hline $\mathrm{J}$ & 0.754 & 90 & 0.789 & 90 \\
\hline $\mathrm{K}$ & 0.781 & 70 & 0.791 & 90 \\
\hline $\mathrm{L}$ & 0.683 & 0 & 0.755 & 100 \\
\hline 総合 & 0.799 & 86 & 0.839 & 96 \\
\hline
\end{tabular}

須である。

成人男子 $\mathrm{A} \sim \mathrm{L}$ の 12 人から採取したサンプルの中 で評価值 $\eta^{*}$ が最も大きい指紋画像を 1 指ずつ選び特 徵点抽出率を調べた。その結果を表 1 に示す。ここ 
で, 正抽出率および擬似特徵率は，

$$
\begin{aligned}
& \text { 正抽出率 }=\frac{\text { 抽出できた真の特徵点数 }}{\text { 抽出すべき真の特徵点数 }} \\
& \text { 擬似特徵率 }=\frac{\text { 抽出した擬似特徵点数 }}{\text { 抽出した全特徵点数 }}
\end{aligned}
$$

と定義した。それぞれ真の特徵点がどの程度抽出でき たか, 隆線の癒着や切れなどによって発生した偽の分 岐点や端点からなる擬似特徵点がどの程度含まれてい るかを示す。したがって，正抽出率は高く，擬似特徵 率は低いことが望ましい。 また，表 2 には表 1 の指紋 を基準指紋として選び，それぞれ 10 個の入力指紋と の本人間照合を行った結果を示す．同表の $\eta^{*}$ の平均 は 10 個の入力指紋画像の平均值である.

サンプル $\mathrm{A} \sim \mathrm{G}$ の画像については両検出方法とも に $\eta^{*}$ が大きく良質な画像であったので正抽出率は 70 $\%$ 以上と高く，擬似特徵率は $45 \%$ 以下と低く抑えら れ, 正照合率は $100 \%$ となった。しかし, サンプル H 〜 L は画質の劣化に伴い正抽出率が $60 \%$ 前後に低下 し擬似特徵率は $60 \%$ を越え，入力指紋に不一致と判 定される例が現れた．特にサンプル L は指表面の乾 燥がひどく， $\eta^{*}$ は両方法とも最低值を示した。この 場合, 全反射法の正抽出率は $42.3 \%$ と最低值をとり, 正照合率は $0 \%$ であった。一方，光路分離法では正抽 出率が $62.5 \%$ と高く, 正照合率は 100\%であった。

総合的に光路分離法の方が標準偏差 $\sigma$, 評価值 $\eta^{*}$, 正抽出率, 正照合率は高く, 擬似特徵率は低かった. この点より光路分離法は指の表面状態等の影響を受け にくいことがわかる。

\section{5.む す び}

本論文では小型で安価な指紋照合装置で高速，高精 度の照合を行うには高品質な指紋画像の入力が必要で あるという観点から，指紋検出方法を画質に着目して
比較した。その結果から光学的な方法により鮮明な指 紋画像を得るためには指表面が適度に湿っていること が必要である．特に全反射法では指表面の乾燥した指 紋が入力された場合, 検出画像の質は著しく劣化する ため，照合に必要な指紋情報を充分に抽出できない。 一方, 光路分離法では指表面の乾燥による画質劣化は 避けられなかったが，指紋情報は比較的に安定して抽 出でき高精度の照合が可能であり，全反射法に比べ良 い方法であることがわかった。

最後に, 本実験の遂行に際し多大なご協力を頂いた 宮治伸氏(現, 三洋電機(株))に感謝する。

\section{〔参 考 文 献〕}

1）星野：“指紋照合装置の動向, 信学技報, PRU 88-34（July 1988)

2) 大和, 中島, 橋本, 矢頭：“ICカードを用いた個人確認システ ム”,第 3 回ソフトウェアコンファレンス, pp. 255-258 (Mar. 1986)

3）河越, 棟上：“指紋パターンの自動分類”, 情処学コンピュー タビジョン研資, 18-2 (May 1982)

4）清水,長谷：“プリズムを用いた指紋情報検出方法”，信学論 (D) , J67-D, 5, pp. 627-628 (May 1984)

5）井垣, 矢作, 江口, 山岸, 池田, 稲垣：“ホログラフィック指紋 センサを用いた個人照合装置”, 信学技報, PRU 88-38（July 1988)

6) R. C. Fowler, K. Ruby and T. F. Sartor, Jr.: "Fingerprint Imaging Apparatus", US Patent, 4,537,484 (Aug. 27, 1985)

7）大津：“判別および最小 2 乗規準に基づく自動しきい值選定 法” , 信学論 (D), J63-D, 4, pp. 349-356 (Apr. 1980)

8）清水, 長谷：“プリズムを用いた指紋情報検出方法一全反射 法と光路分離法の比較一”，信学論 (D), J68-D, 3, pp. 414415 (Mar. 1985)

9）大和, 畑, 矢頭, 橋本：“谷細線化による指紋照合システム”, 信学論 (D), J71-D, 2, pp. 327-335（Feb. 1988）

10）宮治, 橋本, 中島, 大和：“指紋画像に対する指の表面状態の 影響”，テレビ学技報, 12, 50, pp. 19-24（Nov. 1988）

11）宮治, 中島, 大和：“指紋画像に対する指の表面状態の影響”, 昭 63 関西連大, G 15-8（1988）

12）大和, 中島, 鈴木, 田中：“マイクロコンピュータを用いた指 紋特徵点のパターンマッチング”, 画電学誌, 16, 4 (Apr. 1987)

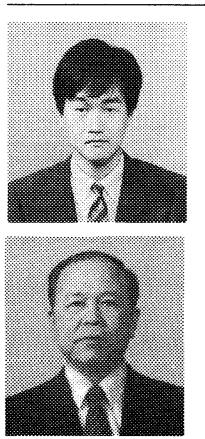

はしもと省本折

哲 昭和 61 年, 姫路工業大学工 学部電子工学科卒業. 63 年, 同大学大学院 修士課程修了. 現在, 同大学院博士課程在学 中.ダイキン工業(株)に勤務. 画像処理, 指 紋による個人確認システムに関する研究に従 事. 正会員.

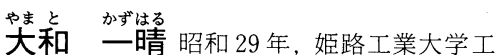
学部電気工学科卒業. 同年, 同大学助手, 講 師, 助教授を経て，46 年, 同大学 (電子) 教 授. 現在, 多値論理, 画像処理, 情報セキュ リティ, 音声認識および信頼性に関する研究 に従事. 工学博士. 正会員.

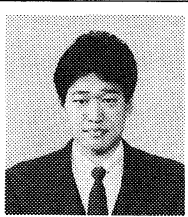

畑祭㽡 昭和 59 年, 姫路工業大学工 学部電子工学科卒業. 平成元年, 同大学大学 院博士課程修了. 同年, 同大学電子工学科助 手となり，現在に至る。多值論理，指紋によ る個人確認システムに関する研究に従事.工 学博士.

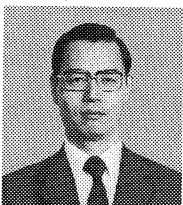

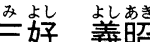
和 42 年，姫路工業大学工 学部電気工学科卒業. 同年, 同大学電子工学 科助手. 音声の分析および認識。ディジタル 信号処理などの研究に従事. 工学博士. 


\section{CCIR勧告601に準拠した高画質 3 次元ディジタルカラーレコーダの開発}

伊藤信悦，大場吉延，Robert Lowlor，海老原規郎

本カラーデコーダは, コンポジットテレビジョン映像信号を輝度信号と, 色(差)信号からなるコ ンポーネント映像信号に変換する装置である.カラーデコーダの高画質化の試みは，コンポジット 映像信号の持つ 3 次元時空間多重スペクトラム構造に起因する $\mathrm{Y} ・ \mathrm{C}$ 分離の困難さのため充分な成 果が得られていなかった．筆者らは，取扱うすべての信号が CCIR 勧告 601 のディジタルコンポー ネント映像符号化規格に準拠したディジタルコンポーネントシステムを構築するにあたり，コンポ ジット映像信号で制作された番組素材をこのシステムに取込む必要性から，高画質な 3 次元ディジ タルカラーデコーダを開発した．Y・C 分離回路には，各画素がもつ $\mathrm{Y} ・ \mathrm{C}$ 間のフロストークを, フ ィールド間時空間斜めくし形フィルタ,フィールド内垂直（ライン間）〈し形フィルタでそれぞれ 測定し，その結果を用いて $\mathrm{Y} ・ \mathrm{C}$ 分離用の時空間斜め, フィールド内垂直各くし形フィルタ, およ び、フィールド内水平バンドパスフィルタの出力量を，それぞれ適応的に制御する新しい方式を考 案し, 実現した。この結果, 映像信号の動き量のいかんに関らず, クロスカラー, クロスルミナン ス, ドット妨害の無い, 高画質コンポーネント映像信号が得られた。なお。この 3 次元ディジタル カラーデコーダは,コーディングパラメータを含めて, CCIR 勧告 601 に完全準拠し, 内部のシス テムクロックは $13.5 \mathrm{MHz}$ で統一され，また，NTSH，PAL，PAL-M の各映像信号を同一ハー ドウエアでワンタッチで切替えてデコードできるように構成されている.

テレビジョン学会誌 Vol. 44, No. 9, pp. 1239〜1245 (1990)

\section{指紋画像に対する指の表面状態の影響}

橋本 哲, 畑 豊, 三好義昭, 大和一晴

光学的な指紋検出方法として光路分離法と全反射法などが一般に用いられているが，その光学的 な特性は明かでない. 光学的に検出した指紋面像の品質が指紋表面の湿り具合いや光源の明るさ， 指紋入力面の污れにより，どの程度影響を受けるか調べた。まず，光学的な指紋検出方法を紹介 し，基本的な指紋検出方法である全反射法と光路分離法を用いて行った社験について述べる．実験 結果より，指の表面が乾燥していた場合，全反射法による検出画像は著しく画質が劣化するため照 合に必要な指紋情報を充分抽出できない，一方，光路分離法でも指表面の乾燥により，検出画像の 品質は多小劣化するが比較的安定して指紋情報が抽出できるため高精度の照合が行えることを確認 した．また，検出画像の品質は光源の照度により変化する.最適な光源照度は指の表面状態により 異なる．指紋入力面の污れの影響は高照度側で顕著に現れることがわかった．

テレビジョン学会誌 Vol. 44, No. 9, pp. 1246〜1252 (1990)

\section{フェライトを用いたテレビゴースト防止対策用 3 層型電波吸収体}

橋本康雄, 栗原 弘, 平井義人, 石野 健, 清水康敬

建造物により発生するテレビ電波反射障害対策として，その壁面をフェライトで構成する方法が 有効であり，すでに数多く実用化されている．特に，高層ビルに取り付けるための電波吸収体に対 しては建築上の強度, 耐久性抢よび外壁としての美観が要求されるため, 天然石を外装材として用 いる場合 $25 \mathrm{~mm}$ 以上の厚い表面層を施し，フェライト層およびコンクリート層からなる 3 層構造 電波吸収体が望ましい。ここでは，強度，耐久性の面から表面層を厚くした場合における電波吸収 特性への影響を検討した，その結果，表面層を厚くすると高周波側の電波吸収特性が劣化すること がわった，そのため，特性改善策として磁界方向に連続配列されたフェライトタイル間に磁気抵抗 制御のための適切なスリットを配置することにより，テレビ周波数帯で良好な電波吸収特性が得ら れることを明らかにした。 そして, 実用的な $3 \mathrm{~m} \times 4 \mathrm{~m}$ の電波吸収体パネルによる評価を行い, 強 度および美観にも優れるテレビゴースト防止対策用電波吸収体が実現できた。 